\title{
DEVELOPMENT AND EVALUATION OF CERAMIC TILES USING WASTES AND SOLID MINERALS
}

\author{
Z.U. Elakhame ${ }^{* a}$, Y.L. Shuaib-Babata ${ }^{\mathrm{b}}$, and I.O. Ambalic \\ ${ }^{a}$ Department of Prototype Design and Development, Federal Institute of Industrial Research, Lagos, Nigeria. \\ ${ }^{\mathrm{b}}$ Department of Materials and Metallurgical Engineering, University of Ilorin, Ilorin, Nigeria. \\ ${ }^{c}$ Department of Materials and Metallurgical Engineering, University of Ilorin, Ilorin, Nigeria.
}

\begin{abstract}
This paper focuses on the need for domesticating the production of building materials like tiles to address the problem of Nigeria over dependence on imported goods, despite adequate availability of mineral resources like clay, quartz and feldspar in the country. Clay, quartz and feldspar, and milled glass were respectively obtained from Ogijo in Ogun State, Okpila in Edo State and Oshodi, Lagos State of Nigeria were characterized using ASTM C71 as a guide. Samples of the ceramic tile were produced from varying mixtures of clay, quartz, feldspar and milled glass. The chemical and physio-mechanical properties of the samples were also determined. The results showed that the clay sample belong to Alumino-silicate group with $59.20 \%$ silica and $21.25 \%$ alumina. The samples' properties met the required standards; hence, the materials were found suitable for production of ceramic tiles of acceptable standards. Though, the porosity of the sample tiles increased as the percentage weight of the clay material in the mixture decreased the proportion of quartz, feldspar and milled glass increased. The sample containing 70\% Clay and 30\% Feldspar had better formulation properties than others.
\end{abstract}

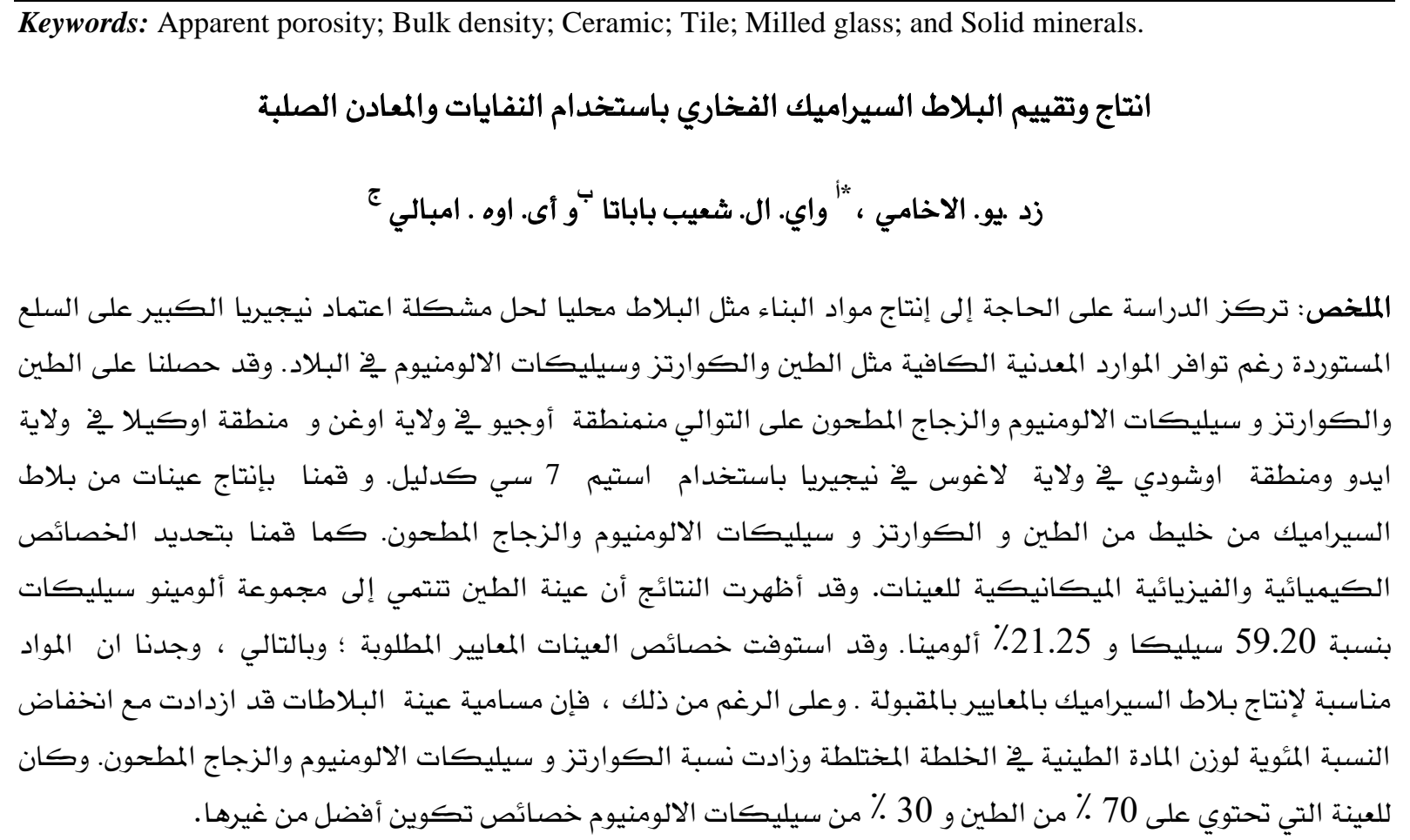

الكلمات المفتاحية: المسامية الظاهرة ؛ الكثافة الرئيسة ؛ السيراميك ؛ البلاط؛ الزجاج المطحون ؛ المعادن الصلبة. 


\section{INTRODUCTION}

In Nigeria, natural mineral resources, such as clay, feldspar, quartz are available in large quantities Shuaib-Babata and Mudiare (2017), but the country is still highly being challenged with economic problems. Some studies have attributed the present Nigeria economic problem to over-dependence on foreign goods, oil and gas and to negligence of other sectors (Chete et al. 2017; Projectsxtra 2017; ShuaibBabata et al. 2017a).

It is claimed that an identified veritable tool towards any nation development is Industrialization (Shuaib-Babata et al. 2017b; Shuaib-Babata et al. 2017c). Availability of mineral resources in Nigeria has been the backbone of the nation's economic and industrial development aspirations Foraminifera (2017). Presently, there are several calls for diversification of Nigeria's economy and significant reduction of its overdependence on oil and gas to come out permanently of the present economic recession Foraminifera (2017).

Production capacity from locally available raw materials used in development of technology in the transformation of the raw materials to finished products is a significant factor towards a successful industrialization (Shuaib-Babata et al. 2017a, ShuaibBabata et al. 2017b). The identified bases for the development of any industrial sector include access to raw materials, labor force, funds and technology Hughes (2008). Effective industrialization could be significant to reduce overdependence of a nation on foreign goods and enhance export base ShuaibBabata et al. (2017a).

Worldwide, production and consumption of ceramic tiles has recently increased all over the world as result of rapid development of real estate industry WIFI Ceramics (2017). The tiles used in the estate development are of different quality; it ranges from high to middle and low quality, which is imported to Nigeria, especially from China. With the present call for economic diversification in Nigeria, the need for local production of ceramic tiles with good quality is highly essential. This will be of help to proffer a solution to the problem and sustain the country economy through industrialization.

There have been numerous attempts to utilize either industrial or agricultural wastes in the manufacture of wall and floor ceramic tiles in the past last two decades (Elakhame et. al. 2016; Cesar et al. 2011; Juan, et al. 2010). Industrial wastes are considered to be an important part of the materials used. Cement kiln dust (CKD) as a great trouble maker waste, was utilized in ceramic tile bodies by Youssef (2002), to replace half the feldspar required for ceramic wall tile body with a double target of cost reduction and environment protection. In that study, verification parameters of the fired samples was measured and the water absorption was within both ISO and Egyptian standards limits of wall tiles. CKD in the mixture makes it less dense, more porous and lowers the compressive strength (Safiuddin et al.
2010; Yoshizawa et al. 2004; Central Pollution Control Board (CPCB), 2000; Torgal and Jalali 2010).

For better quality tiles, the basic raw materials employed for the production of ceramic tiles include quartz and feldspar (which serve as a source of silica and alumina to give the tiles the desired strength) and clay from a good source to serve as binder. In this study, milled glass and aluminum were considered as a primary source of alumina and silica.

This study aims at the development of standard composite ceramic tiles-based (CCT) using available mineral resources and wastes to aid local production of building materials in Nigeria. It also focuses on the use of cheaper and durable materials to fabricate the CCT to enhance its properties by variation of fillers to identify the best mechanical and physical properties of the produced tiles. In the end, this should assist in solving the problem of unemployment among youths. It should also help in diversification of economy and solve the problem of over dependence on the oil and gas sectors, which had led to economic recession in the country.

\section{MATERIALS AND METHODS}

\subsection{Materials}

In this study, the major materials used include clay (CY), quartz (QZ), Feldspar (FR) and milled glass (MG). The clay material and the milled glass bottle was sourced from Ogijo-Shagamu Area, Ogun State and Oshodi, Lagos Nigeria respectively. The quartz and feldspar were obtained at different deposits in Okpila, Edo State, Nigeria. Samples of the raw materials for the production of ceramic tiles in solid forms are shown in Fig 1.

\subsection{Methods}

\subsubsection{Chemical Analysis}

The chemical compositions of the representative samples of the clay, quartz, feldspar and milled glass were determined at Engineering Materials Development Institute (EMDI), Akure, Nigeria using Atomic Absorption Spectrometer (AAS) UNICAM 929. This is in line with the data reported by (Ryan 1978; Yoshizawa et al. 2004; and Safiuddin, et al. 2010).

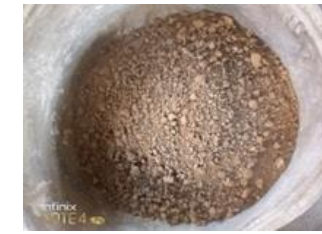
Clay

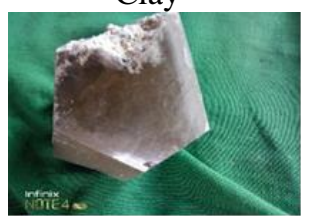

Quartz

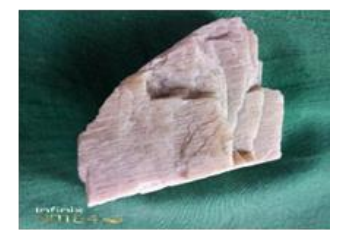

Feldspar

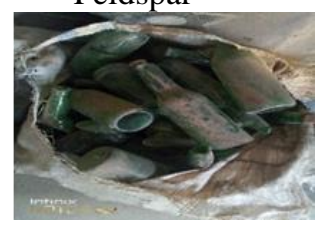

Glass Bottles
Figure 1. Samples of the raw materials used for the production of ceramic tiles. 


\subsubsection{Preparation of Materials}

\subsubsection{Clay Materials}

To remove debris and other unwanted materials in the clay sample, the clay was soaked in water for five (5) days, sieved with a mesh of $350 \mu \mathrm{m}$ and dried at room temperature for one week (7 days). Subsequently, the dried sample was milled and sieved into $100 \mu \mathrm{m}$ sizes in line with the practice of Elakhame et al. (2016b).

\subsubsection{Quartz, Feldspar and Milled Bottle.}

The quartz and feldspar and the milled glass bottle (additive materials) were crushed using a
Hammer Milling Machine (Model; 000T, PUISSANE; 1.5KV, S/N; 13634) and milled into fine size particles using ball-milling machine (Model; 87002 .... Limoges-France, Type; A50---43), and then sieved with a Vibro-Sieve (Model; Fritsch GmbH, D55743.1 Dar-Oberstein Germany) into $100 \mu \mathrm{m}$ particles size.

\subsubsection{Raw Materials Mixtures}

In forming the raw materials mixtures for the production of ceramic tiles, milled bottle, quartz and felspar were added to the clay materials at different proportion as presented in Table 1 ( $\mathrm{a} \& \mathrm{~b})$.

Table 1a. Proportion of clay and other materials in forming the raw mixes for the production of ceramic tiles (Formulation A-C).

\begin{tabular}{|c|c|c|c|c|c|c|}
\hline \multirow[t]{2}{*}{ Samples } & \multicolumn{2}{|c|}{$\begin{array}{c}\text { Sample Formulation } \\
\text { A } \\
\end{array}$} & \multicolumn{2}{|c|}{$\begin{array}{c}\text { Sample Formation } \\
\text { B }\end{array}$} & \multicolumn{2}{|c|}{$\begin{array}{c}\text { Sample Formation } \\
\text { C }\end{array}$} \\
\hline & $\begin{array}{l}\text { CY } \\
(\%)\end{array}$ & $\begin{array}{l}\mathrm{QZ} \\
(\%)\end{array}$ & $\begin{array}{l}\text { CY } \\
(\%)\end{array}$ & $\begin{array}{l}\text { FR } \\
(\%)\end{array}$ & $\begin{array}{l}\text { CY } \\
(\%)\end{array}$ & $\begin{array}{l}\text { MG } \\
(\%)\end{array}$ \\
\hline 1 & 100 & 0 & 100 & 0 & 100 & 0 \\
\hline 2 & 80 & 20 & 80 & 20 & 80 & 20 \\
\hline 3 & 70 & 30 & 70 & 30 & 70 & 30 \\
\hline 4 & 60 & 40 & 60 & 40 & 60 & 40 \\
\hline 5 & 50 & 50 & 50 & 50 & 50 & 50 \\
\hline 6 & 40 & 60 & 40 & 60 & 40 & 60 \\
\hline 7 & 30 & 70 & 30 & 70 & 30 & 70 \\
\hline 8 & 20 & 80 & 20 & 80 & 20 & 80 \\
\hline
\end{tabular}

Table 1b. Proportion of clay and other materials in forming the raw mixes for the production of ceramic tiles (Formulation D.

\begin{tabular}{llll}
\hline \multicolumn{4}{c}{ FORMULATION SAMPLE } \\
& \multicolumn{3}{c}{ D } \\
\hline CY & QZ & FR & MG \\
$(\boldsymbol{\%})$ & $(\boldsymbol{\%})$ & $(\boldsymbol{\%})$ & $(\mathbf{\% )}$ \\
50 & 0 & 40 & 10 \\
50 & 10 & 30 & 10 \\
50 & 40 & 0 & 10 \\
50 & 5 & 5 & 40 \\
0 & 35 & 35 & 30 \\
\hline
\end{tabular}

Note: Clay $=$ CY, Quartz $=$ QZ, Feldspar $=$ FR, and Milled glass $=\mathrm{MG}$

\subsubsection{Tiles Production}

In development of ceramic tile samples, various raw materials mixes were processed sequentially using the process technology flow chart presented in Fig. 2.

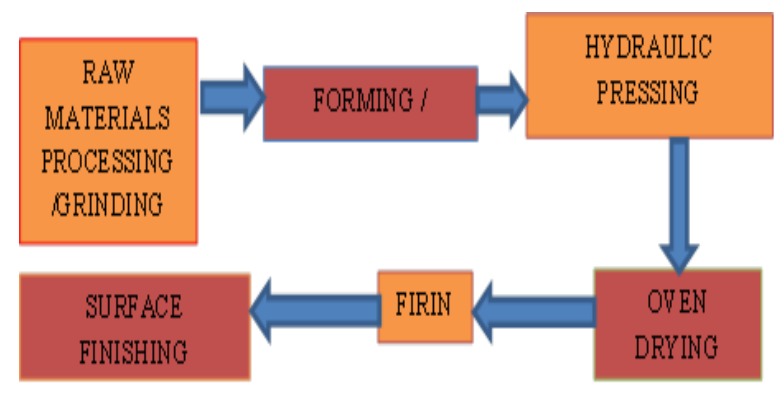

Figure 2. Process technology flow chart.

The milled powder clay, quartz, feldspar and glass bottles were individually measured appropriately as indicated in Table 1 using a $0.001 \mathrm{mg}$ sensitivity weighing scale. The samples were sieved with 100 $\mu \mathrm{m}$ mesh and mixed to homogeneity. Subsequently, the mixed material (granulated powder mixture) was poured into a prepared mould, $5 \mathrm{~cm} \times 5 \mathrm{~cm}$ size (Fig. 3 ) to form shaped test specimens and then uniaxially compacted using hydraulic press (Weber- Hydraulic, AC-8800 Vibrorg, Denmark. Type; p-16H, Capacity; $16 \mathrm{~T}, \mathrm{~S} / \mathrm{N}$; 29580) under a pressure of $50 \mathrm{MPa}$, in accordance with guidelines in mould Pressed Ceramic Tiles - Specification (First Revision of IS 15622) ICS91.100.23. The pressed specimens were held overnight and then dried at $90-100^{\circ} \mathrm{C}$ for 48 hours in an oven.

Dried specimens were fired in a laboratory type electric furnace (Nabertherm, more than heat 30$3000^{\circ} \mathrm{C}$ ) at the rate of $5^{\circ} \mathrm{C} / \mathrm{min}$. The technological parameters values were measured after firing steps. The firing procedure used involves heating the sample at a temperature of $1170^{\circ} \mathrm{C}$, then soaked for 3 hours and naturally cooled Correlia et al. (2004). The procedures were repeated for all the formulations (A- 
D). The produced samples of the ceramic tile specimens produced are shown in Fig. 4.

\subsection{Determination of the Specimens' Properties}

Some properties of the material mixes (moulded specimens) were tested for proper evaluation of their suitability. The properties include fired shrinkage, apparent porosity, bulk density, porosity and compressive strength, chemical composition and microstructural test. For the products to be in compliance with National and International Standards, these properties were evaluated using various national and international test procedures and standards as presented in Table 2 .

\subsubsection{Porosity of the Brick Sample}

Porosity of the brick sample was determined using ASTM JISD4418-1996 guidelines by soaking the bricks in a bath of water at $100^{\circ} \mathrm{C}$ for 8 hours. The mass of each of the samples before and after

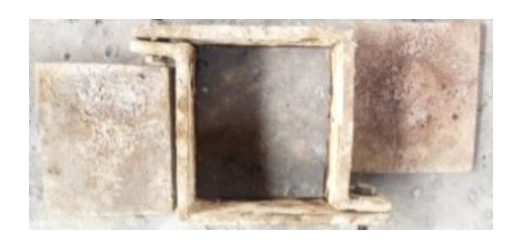

Figure 3a. The Mould.

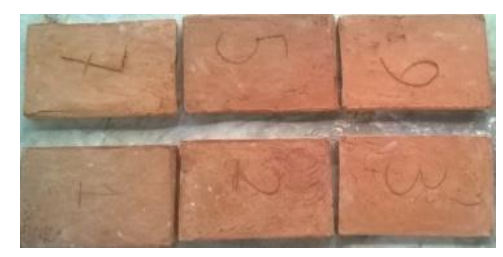

Figure 3b. Samples of ceramic tile specimens.

Table 2. Various National and International test procedures and Standards used for evaluation of the samples.

\begin{tabular}{|c|c|c|}
\hline $\mathbf{S} / \mathbf{N}$ & Test procedures & Standards \\
\hline 1 & Specific gravity & $\begin{array}{l}\text { MS 474: Part 1: } \\
2003\end{array}$ \\
\hline 2 & $\begin{array}{l}\text { Compressive strain test } \\
\text { method }\end{array}$ & $\begin{array}{l}\text { MS ISO } \\
6310: 2003, \\
\text { Part } 4\end{array}$ \\
\hline 3 & $\begin{array}{l}\text { Determination of modulus of } \\
\text { rupture and breaking strength }\end{array}$ & $\begin{array}{l}\text { MS ISO (Part 6): } \\
2006 \text { (first } \\
\text { revision) }\end{array}$ \\
\hline 4 & Shear test procedure & $\begin{array}{l}\text { MS ISO } \\
\text { 6312:2003, Part } 6\end{array}$ \\
\hline 5 & $\begin{array}{l}\text { Determination of thermal } \\
\text { Conductivity }\end{array}$ & ISO 7882: 1986 \\
\hline 6 & $\begin{array}{l}\text { Porosity \& Apparent porosity } \\
\text { measurement }\end{array}$ & JIS D 4418 - 1996 \\
\hline 7 & $\begin{array}{l}\text { Determination of linear } \\
\text { thermal expansion }\end{array}$ & $\begin{array}{l}\text { (Part 4): } 2006 \\
\text { (first revision) }\end{array}$ \\
\hline 9 & $\begin{array}{l}\text { Determination of water } \\
\text { absorption and bulk density. }\end{array}$ & $\begin{array}{l}\text { (Part 2): } 2006 \\
\text { (first revision) }\end{array}$ \\
\hline
\end{tabular}

soaking was determined (in $\mathrm{mg}$ ) and recorded. The porosity of the samples were then determined using equation 1 .

Porosity $(\mathrm{p})=\left(\frac{M_{1}-M_{2}}{\rho V}\right) \times 100$

Where M1 is the mass ( $\mathrm{g}$ ) of brick before soaking, $\mathrm{M} 2$ is the mass ( $\mathrm{g}$ ) of brick after soaking water, $\rho$ is the density of the liquid and $\mathrm{V}$ is the volume of sample $\left(\mathrm{cm}^{3}\right)$.

\subsubsection{Apparent Porosity and Bulk Density of the Brick Samples}

The apparent porosity of each of the brick samples was also determined in accordance with JIS D 4418 1996. Brick samples $\left(5 \times 5 \mathrm{~cm}^{2}\right)$ dimension were used. The samples' dried weight in air $\left(\mathrm{W}_{\mathrm{sw}}\right)$ and the saturated $\left(\mathrm{W}_{\mathrm{sa}}\right)$ of each sample were determined. The apparent porosity $\left(\mathrm{P}_{\mathrm{a}}\right)$ and bulk density $\left(\rho_{\mathrm{b}}\right)$ of each brick was determined using the relationships in equation 2 and 3 respectively.

Apparent porosity $\left(\mathrm{P}_{\mathrm{a}}\right)=\frac{W_{s a}-W_{d a}}{W_{s a}-W_{s w}} \times 100$

Bulk density $\left(\rho_{\mathrm{b}}\right)=\frac{W_{d a}}{W_{s a}-W_{s w}}$

\subsubsection{The Compressive Property}

The compressive property test was conducted on the brick samples using Testometeric Universal Testing Machine [TUF - C- $1000 \mathrm{KN}$ (SI)] as specified by the MS ISO (part 6):2006 standard. Brick samples with diameter of $5 \times 5 \mathrm{~cm}^{2}$ were loaded gradually in compression until the brick failed to offer further resistance to deformation which was indicated by the bricks fracture. Various properties (stress, strain, extension and energy at different stages) of the samples were recorded from the display unit (monitor) attached to the machine.

\subsubsection{Measurement of Fired Shrinkage}

The shrinkage properties of the bricks were determined by measuring both the green and fired dimensions of the $5 \times 5 \mathrm{~cm}^{2}$ brick samples, using Length Comparator with Digital Indicator in accordance with the guidelines in ASTM C227 / and as specified by the ISO 10545-2 standard. Both sides of the specimens were measured and the average linear shrinkage was calculated. The linear shrinkage of each side was calculated as a percentage of the original green dimension as expressed in equation 4 .

Linear Shrinkage $(\mathrm{Ls})=\frac{L_{g}-L_{f}}{L_{g}} \times 100$

where $\mathrm{L}_{\mathrm{g}}$ and $\mathrm{L}_{\mathrm{f}}$ are green and fired length of bricks respectively. 


\section{RESULTS AND DISCUSSION}

\subsection{Materials Chemical Composition}

The results of the chemical analysis in Table 3 show the major constituents of the clays, quartz and feldspar.

\subsection{Porosity and Bulk Density}

The porosity and bulk density values of the various produced moulded ceramic tiles samples are as shown in Fig. 4 and 5 respectively. The specimens' average porosity measurements ranged between 0.1 and $2.7 \%$.

It is shown in the results (Table 2) that $80 \%$ and the above constituents of the clay and feldspar were silica $\left(\mathrm{SiO}_{2}\right)$ and Alumina $\left(\mathrm{Al}_{2} \mathrm{O}_{3}\right)$. Clay possessed $59.2 \%$ silica and $21.25 \%$ alumina, while fledspar had $49.16 \%$ and $34.02 \%$ of silica and alumina respectively. Therefore, the clay and feldspar belong to Alumino-silicate group in line with the view of (Shuaib-Babata 2016; Abolarin et al. 2006; Hassan 1993; Encyclopedia Britannica (2018a; and Bastin 2018). Quartz also had silica as its major constituents with $99.96 \%$ value. Hobalt (2018) and Encyclopedia Britannica (2018b) affirmed that quartz primarily consists of silica.

It is observed from Fig. 4 that the fraction of the volume of the voids over the surface of the specimens produced were very closed-cell foam. However, the results revealed that specimens 6 and 8 in formulation $\mathrm{C}$ had the lowest porosity values of $0.1 \%$. This might be the result of reduction in the clay percentage in the composition of the specimens. Materials with low

Table 3. The Chemical Compositions of all the raw solid minerals.

\begin{tabular}{ccccc}
\hline S/N & Parameters & \multicolumn{3}{c}{ Level of Detection (wt\%) } \\
& & Clay & Quartz & Feldspar \\
\hline 1 & $\mathrm{SiO}_{2}$ & 59.200 & 99.96 & 49.16 \\
2 & $\mathrm{TiO}_{2}$ & 0.005 & 0.047 & 0.01 \\
3 & $\mathrm{Al}_{2} \mathrm{O}_{3}$ & 21.250 & 0.041 & 34.02 \\
4 & $\mathrm{Fe}_{2} \mathrm{O}_{3}$ & 15.700 & 0.006 & 0.74 \\
5 & $\mathrm{CaO}$ & 1.920 & 0.100 & 2.87 \\
6 & $\mathrm{MgO}$ & 0.880 & 0.007 & 0.08 \\
7 & $\mathrm{Na} 2$ & 0.050 & 0.000 & 2.63 \\
8 & $\mathrm{~K} 2 \mathrm{O}$ & 0.040 & 0.000 & 8.40 \\
9 & $\mathrm{MnO}$ & 0.010 & 0.008 & 0.002 \\
10 & $\mathrm{Moisture}$ & 0.002 & 0.001 & 0.005 \\
\hline
\end{tabular}

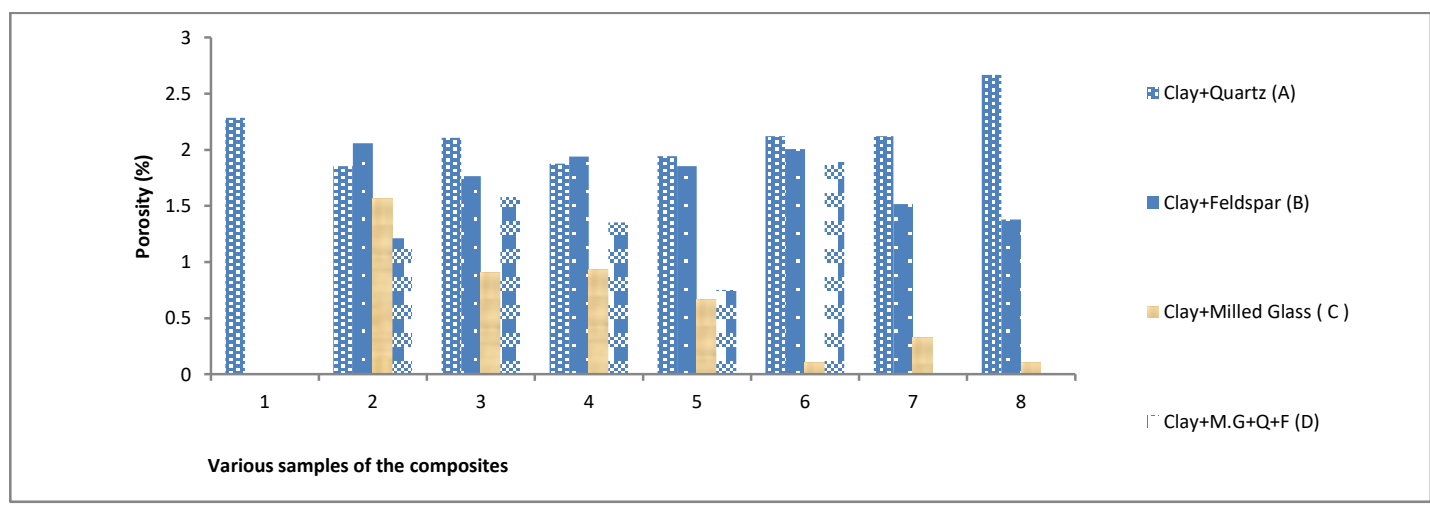

Figure 4. Average porosity values of different moulded ceramic tiles samples with varying Compositions.

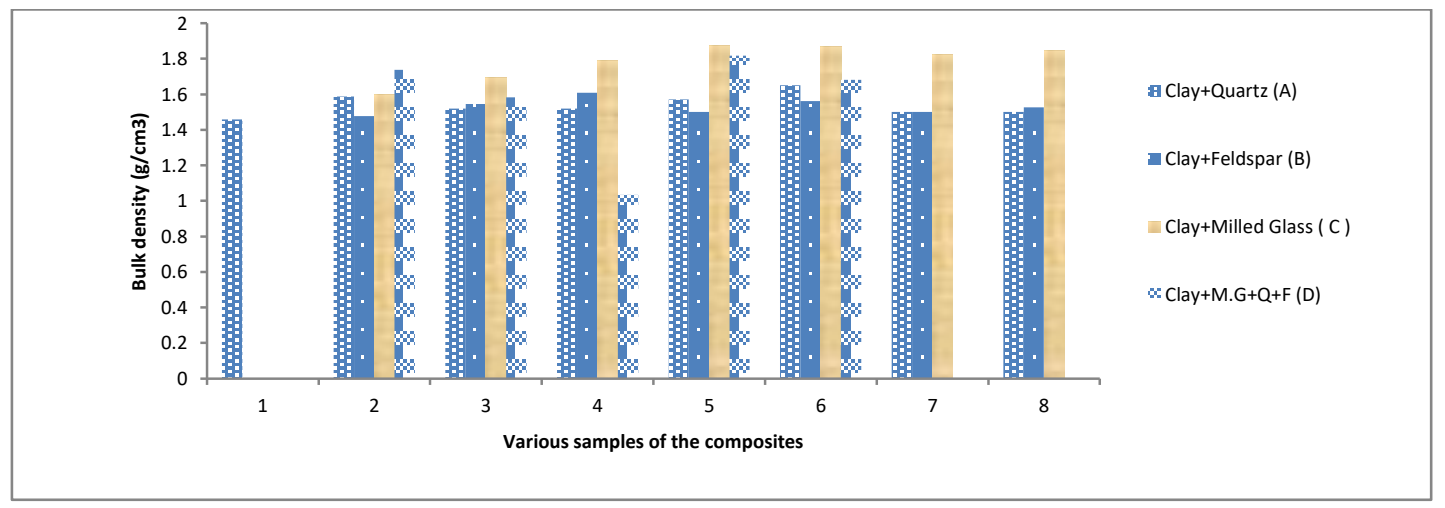

Figure 5. Average bulk density values of different moulded ceramic tiles samples with varying composition. 


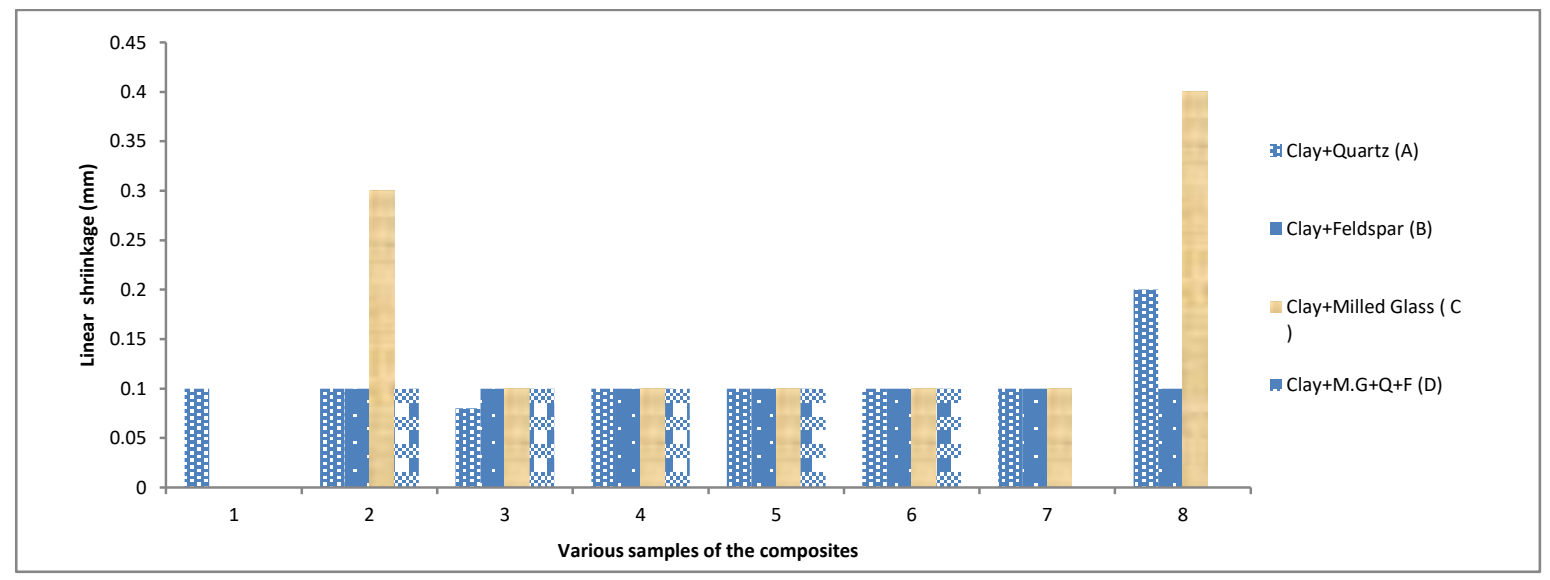

Figure 6. Average linear shrinkage values of different moulded ceramic tiles samples with varying Compositions.

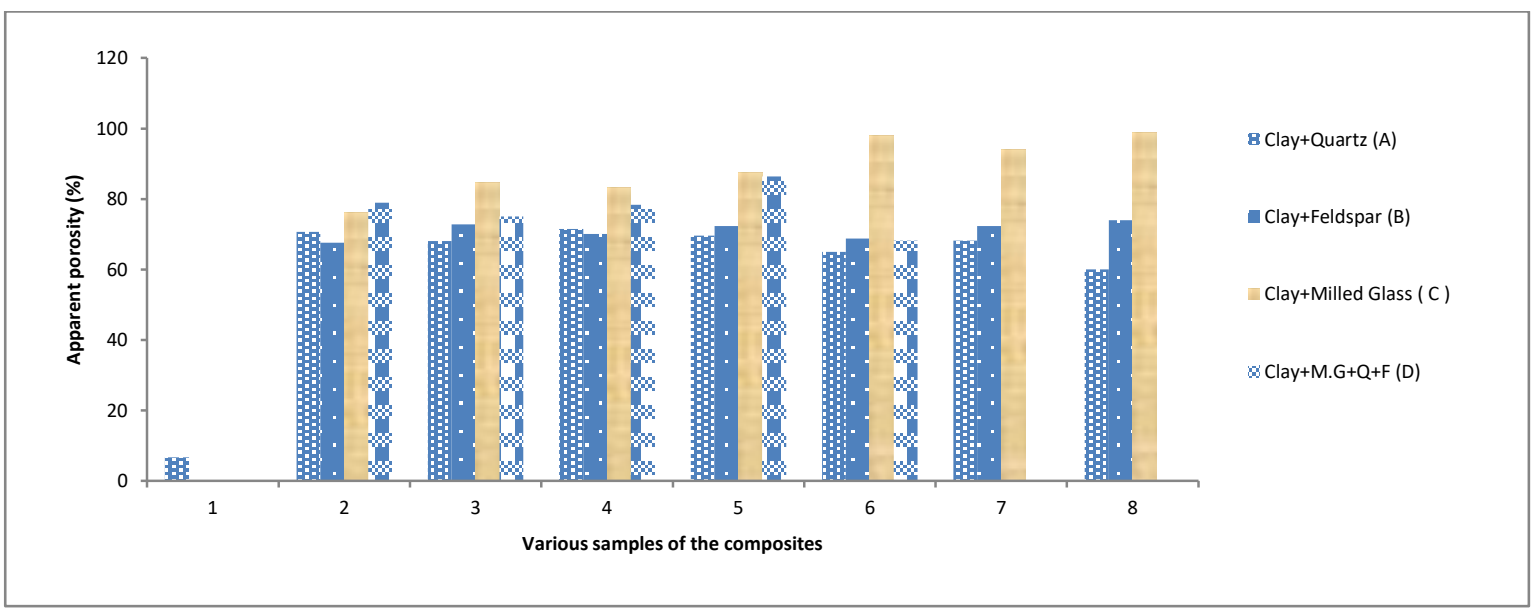

Figure 7. Apparent porosity values of different moulded ceramic tiles samples with varying Compositions.
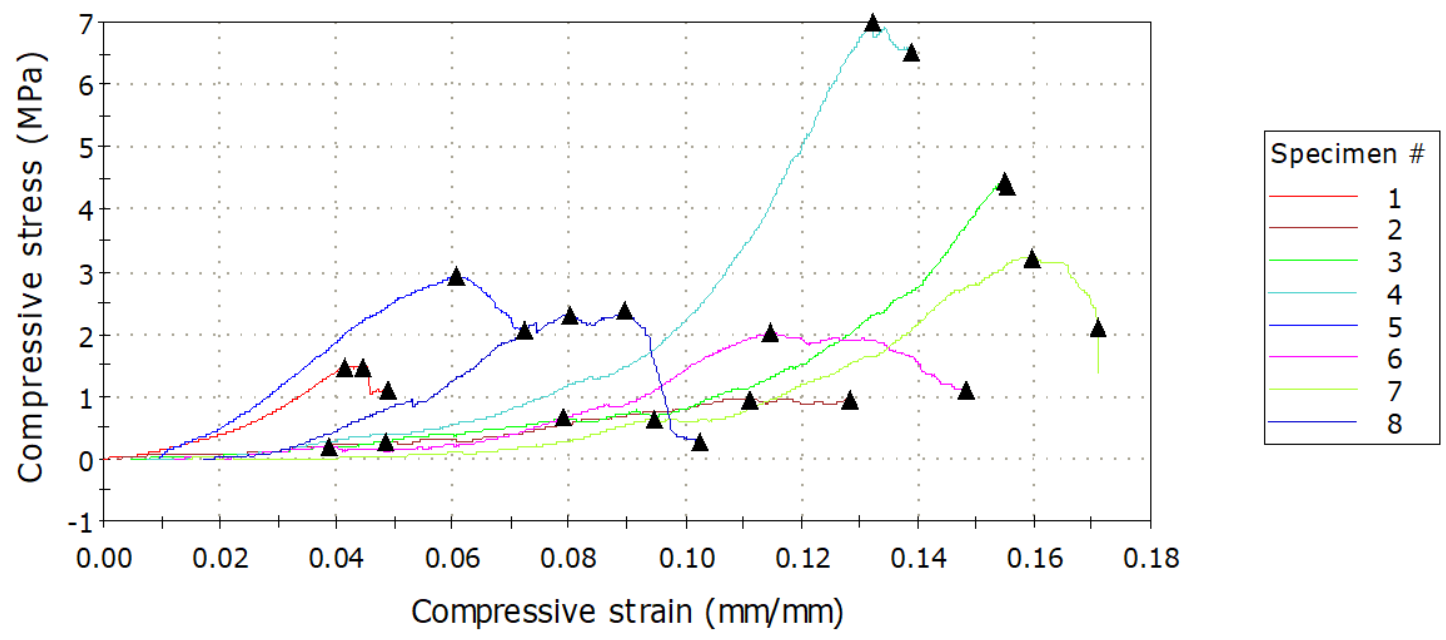

Figure 8. Stress - strain relationship in formulation A. 
porosity value are more preferred for production of tiles Elakheme et al. (2016). Generally, the average porosity values were within the recommended value of $0.1-3.5 \%$ for tiles (National Research Council of Italy, 2017).

The specimens' average bulk densities were within 1.033 and $1.875 \mathrm{~g} / \mathrm{cm}^{3}$ (Fig. 5), which fall within the recommended standard bulk density range of 1.0 to $2.5 \mathrm{~g} / \mathrm{cm}^{3}$ for tiles (Hassan, 2011; National Research Council of Italy, 2017) and $1.7-2.1 \mathrm{~g} / \mathrm{cm} 3$ for dense ceramic materials Hassan (2001). Sample 4 in formulation $\mathrm{D}$ had the lowest bulk density value of $1.033 \mathrm{~g} / \mathrm{cm}^{3}$, while samples $5 \& 6$ in body formulation $\mathrm{C}$ recorded the highest value of 1.87 $\mathrm{g} / \mathrm{cm}^{3}$. Materials with low density would be better for production of tile.

\subsection{Fired Shrinkage and Apparent Porosity}

The samples' linear shrinkage ranged between 0.08 and $0.40 \mathrm{~mm}$ (Fig. 6), which were within the accepted range of 0.02 and $0.80 \mathrm{~mm}$ (National Research Council of Italy, 2017). The samples' linear shrinkage values at $1100^{\circ} \mathrm{C}$ were significantly low. This is very advantageous for wall and floor tiles composition, which may be due to the presence of appreciable $\mathrm{SiO}_{2}$ in the composition. However, the magnitude of shrinkage increases with clay contents but the limit is reached for higher specific water contents Boivin et al. (2004).

The samples' calculated percentage apparent porosity ranged between 45.0 to $98.1 \%$. These values were within the specified 30.0 to $60.0 \%$ values (National Research Council of Italy, 2017). Sample 8 in formulation A ( $80 \%$ and $20 \%$ quartz) had the lowest apparent porosity value of $45 \%$, which is considered to be the best. This might be attributed to high proportion of $\mathrm{SiO}_{2}$ in the composition. High shrinkage resulted to reduced apparent porosity in the closure of internal pores.

\subsection{Compressive Strength Test}

Figs. 8 to 11 show the stress-strain relation of the samples, which are better illustrated in Figs. 12 and 13 as an indicator for durability of the samples in service.

The variations of calculated apparent porosity values in various samples of the composite are as presented in Fig. 7.
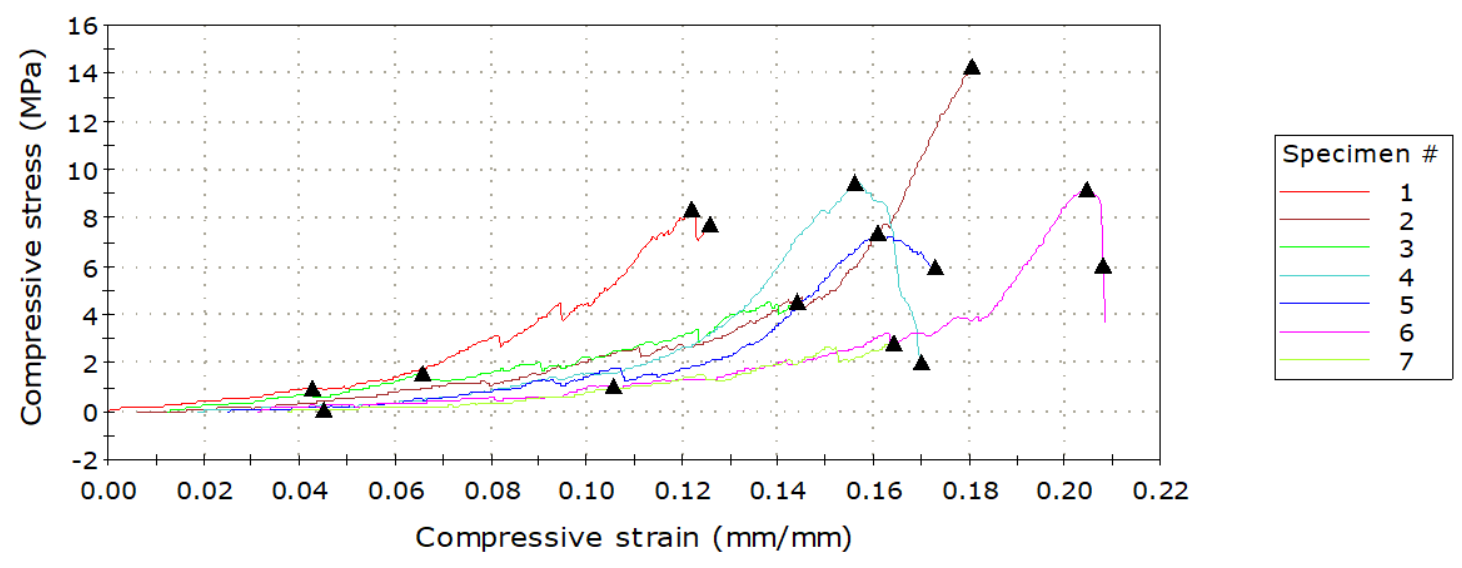

Figure 9. Stress-strain relationship in formulation B.
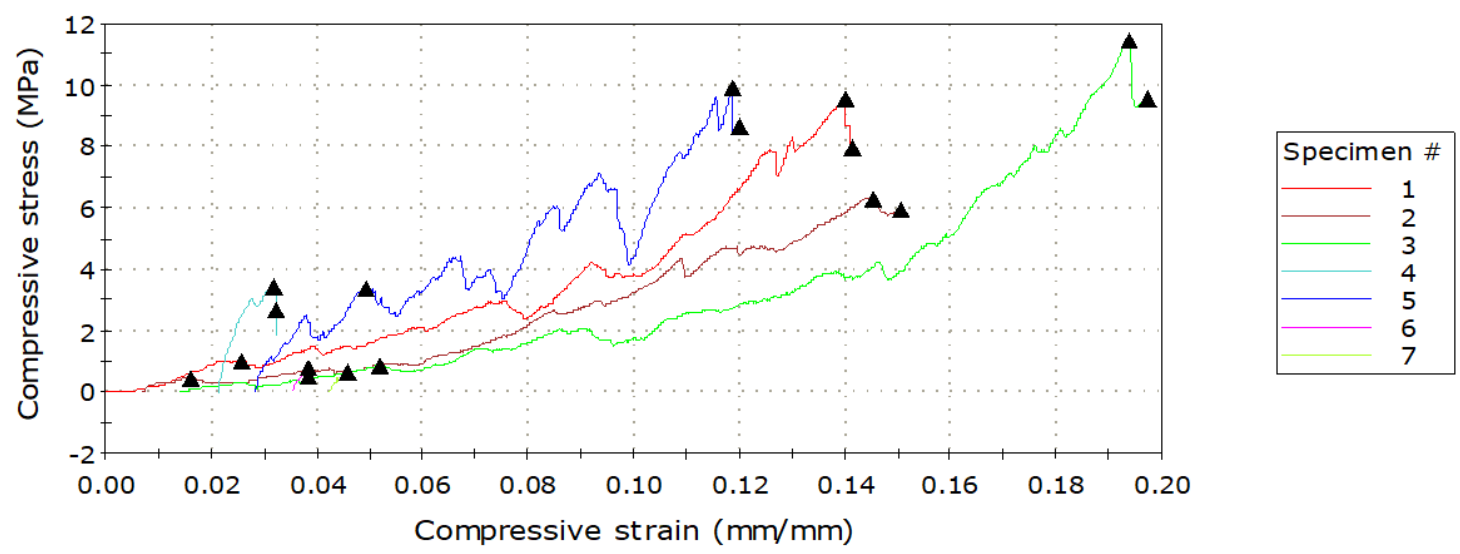

Figure 10. Stress-strain relationship in formulation C. 

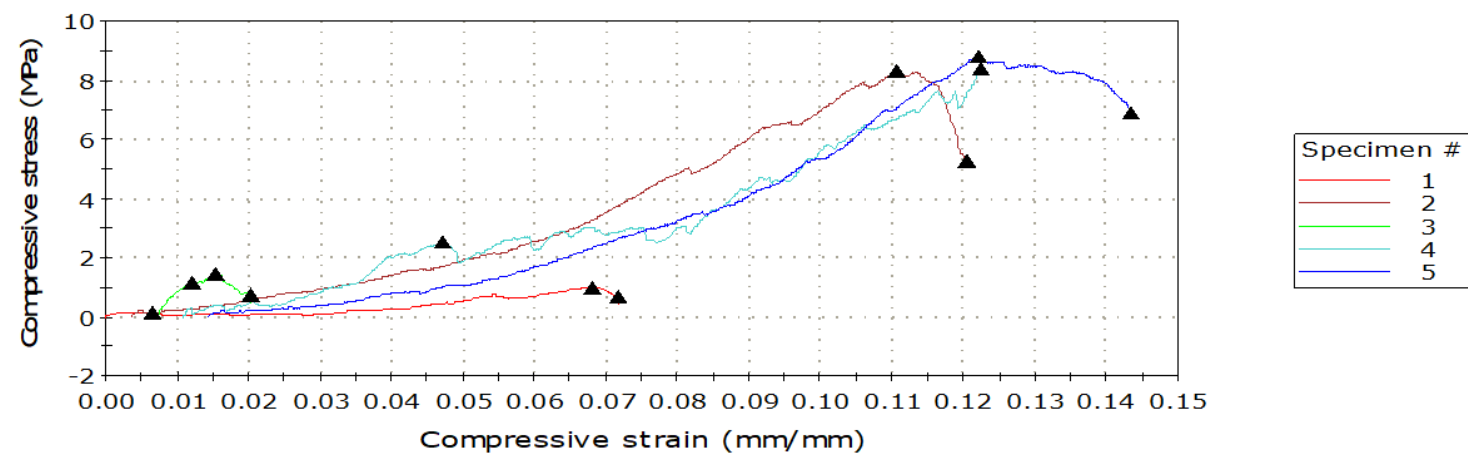

Figure 11. Stress-strain relationship in formulation D.

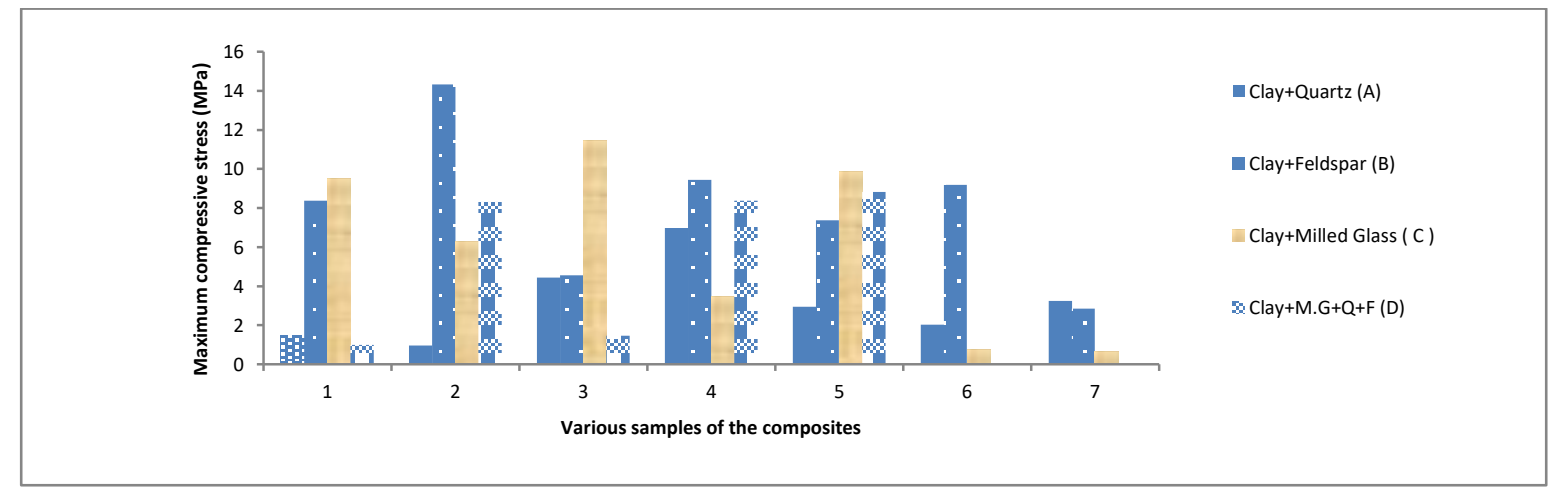

Figure 12. Average Compressive strength values of different moulded ceramic tiles samples with varying composition.

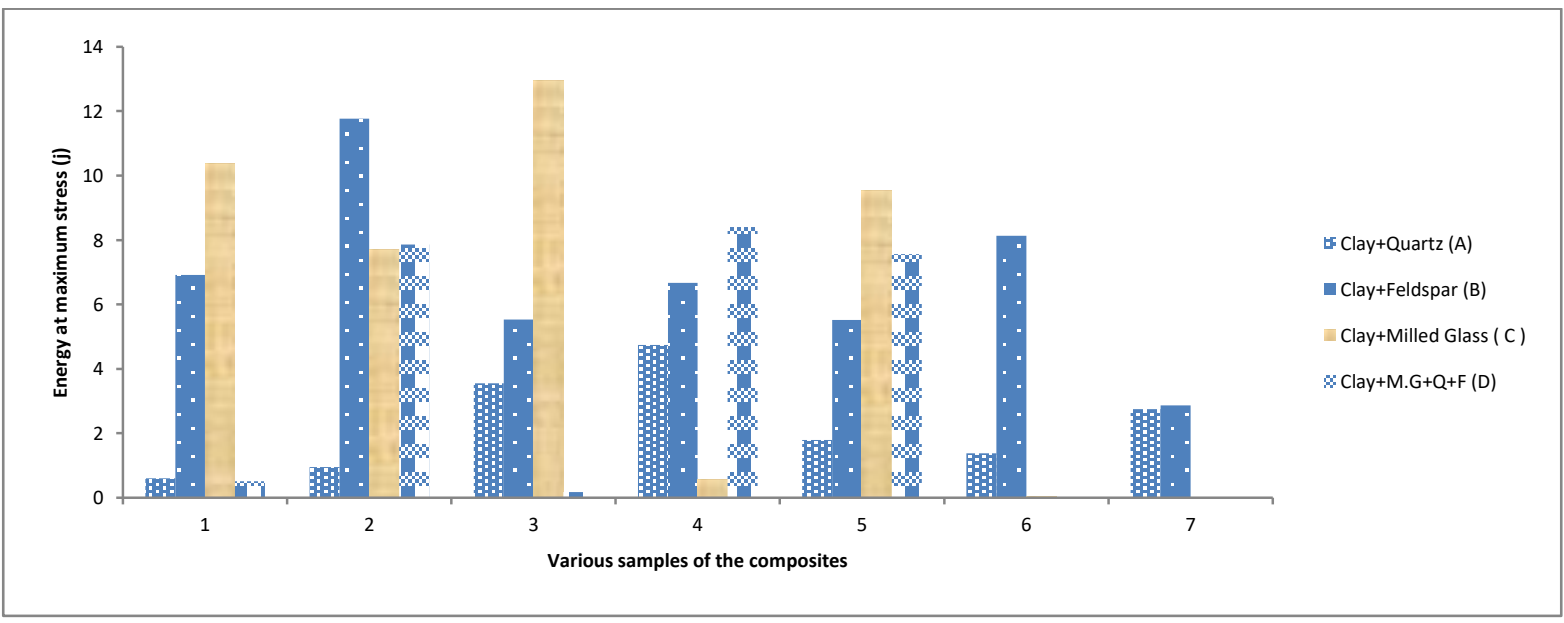

Figure 13. Average energy at maximum stress by different moulded ceramic tiles samples with varying composition.

Table 4. Summary of the sample's properties compared with the available information on the properties of tiles.

\begin{tabular}{cccc}
\hline S/N & Properties & $\begin{array}{c}\text { Tiles } \\
\text { \{CY + QZ \& Dolomite }\} \\
\text { [National Research } \\
\text { Italy, 2017] }\end{array}$ & $\begin{array}{c}\text { New Formulation Lab. Tiles } \\
\text { [CY + QZ + MG \& Alumina }\}\end{array}$ \\
\hline 1 & $\begin{array}{c}\text { Compressive } \\
\text { strength (MPa) } \\
\text { Bulk density } \\
(\mathrm{g} / \mathrm{cm} 3)\end{array}$ & $5.000-20.800$ & $1.0117-14.331$ \\
2 & $1.0-2.5$ & $1.2-1.8$ \\
3 & $\begin{array}{c}\text { Porosity } \\
\text { measurement } \\
(\%)\end{array}$ & $0.1-3.5$ & $0.1-2.7$ \\
4 & $\begin{array}{c}\text { Apparent } \\
\text { Porosity } \%\end{array}$ & $30-60$ & $45-98$ \\
5 & $\begin{array}{c}\text { Shrinkage } \\
\text { measurement }\end{array}$ & $0.02-0.80$ & $0.08-0.4$ \\
\hline
\end{tabular}


Within the formulation A, B, C and D, sample 4, 2, 5 and 4 exhibited the highest compressive strength values of $6.98156 \mathrm{MPa}, 14,33139 \mathrm{MPa}, 11.45160$ $\mathrm{MPa}$ and $8.83201 \mathrm{MPa}$ respectively in each formulation group. These strength values were within the recommended range of 5.00 to $20.8 \mathrm{MPa}$ for tiles Krivandin and Markiov (1980). However, other samples that had strength values within the recommended values include samples $1,2,4,5$ and 6 in formulation B, samples 1, 2, 3 and 4 in formulation B, and samples 2, 4 and 5 in formulation C (Fig. 12). From the obtained results, sample 2 in formulation B consisting of $80 \%$ clay and $20 \%$ feldspar exhibited the highest average compressive strength values $(14,33139 \mathrm{MPa})$. This might be as a result of combination of high $\mathrm{SiO}_{2}$ with $\mathrm{Al}_{2} \mathrm{O}_{3}$ from both clay and feldspar.

Samples 4, 2, 5 and 4 respectively in formulation A, B, C and D also had energy at maximum stress of $4.74391 \mathrm{~J}, 11.77584 \mathrm{~J}, 9.53256 \mathrm{~J}$ and $7.5682 \mathrm{~J}$ respectively, in each formulation group. Generally, the energy values exhibited by the samples ranged between 0.02818 and $11.77584 \mathrm{~J}$. The majority of these energy values were considered to be adequate for sustainability of the tiles in service.

To determine the stability of the samples, it is essential to compare the properties exhibited by the samples with that of available information on the properties of ceramics tiles as presented in Table 4.

Thorough critical study of the data in Table 3 shows that various properties exhibited by sample 4 (formulation A), sample 2 (formulation B), sample 5 (formulation C) and sample 4 (formulation D) met the required standards for tiles. Therefore, the new formulation for production of ceramics tiles using locally available raw materials (clay, quartz, feldspar and milled bottles) proved suitable and adequate for local production of composite ceramic tiles in terms of strength and other properties. This will assist to address the nation's economic problems and help towards job creation.

\section{CONCLUSION}

From this study, the following conclusions are drawn:

1. The clay and feldspar used in this study were found to belong to alumino-silicate group.

2. Suitable combinations of Nigerian natural resources and wastes such clay, feldspar, quartz and milled glasses were found suitable for the production of standard ceramic tiles. The suitable proportions of the materials in production of the tiles: 60: 40\%, 80:20\%, 50:50\% and 60:5:5:30\% of clay and quartz, clay and feldspar, clay, quartz and feldspar, quartz, feldspar and milled glasses respectively.

3. Clay, quartz, feldspar and milled glasses were characterized to ascertain for their potentials for ceramic tiles, refractory and others ceramics applications. The results obtained showed that they meet the criteria for use as refractory/ceramic raw materials in the entire characteristic investigated via chemical composition, fired shrinkage, porosity, apparent porosity, bulk density and compressive strength. The clay can be used as a fired refractory, while quartz, feldspar and milled bottles could be used as a source of silica and alumina for ceramic products.

4. Adequate utilization of available natural resources and wastes in Nigeria such as clay, quartz, feldspar and milled glasses will help in domesticating production of building materials like tiles.

\section{CONFLICT OF INTEREST}

The authors declare no conflicts of interest.

\section{FUNDING}

No funding was received for this project.

\section{REFERENCES}

Abolarin M.S. Olugboji O.A. Ugwuoke I.C. (2006), Determination of moulding properties of locally available clays for casting operations. Assumption University Journal of Technolog, 9(4): 238-242

Bastin E.S. Quartz and feldspar: Quartz and feldspar of maine. Contributions to economic geology, Part I. Available online: https:// pubs.usgs.gov/ bul/ 03151/report.pdf, accessed on December 20, 2018.

Central Pollution Control Board (CPCB) (2000), Report on management of municipal solid wastes, India, Delhi: Central Pollution Control Board.

Cesar M, Sánchez de Rojas M. I. Moisés F, Andrés J (2011), Using ceramic materials in ecoefficient concrete and precast concrete products. Advances in Ceramics - Electric and Magnetic Ceramics, Bioceramics, Ceramics and Environment (24): 533550, DOI:10.5772/21302

Chete L.N. Adeoti J.O. Adeyinka F.M. Ogundele O (2017), Industrial development and growth in Nigeria: Lesson and challenges, leaning to complete working paper No. 8, African growth initiative at Brookings Institute/African Development Bank Group / United Nations, University UNU-Wider World Institute for Development. Available online: https:// www.brookings.edu/wp-content/uploads/ 2016/07/ L2C_WP8_Chete-et-al-1.pdf, accessed on August 22, 2017.

Elakhame Z. U. Ifebhor F, Asotah W. A. (2016), Development and production of ceramic tiles from waste bottle powder (milled glass), Kathmandu University Journal of Science, Engineering and Technology (KUSET), 12(II): 50-59.

Elakhame Z, Bello S. A. Agunsoye J.O. Patric I. Otitoju O (2016b), Characterization of Ujogba clay deposits in Edo State, Nigeria for refractory applications. Kathmadu University Journal of 
Science, Engineering and Technology (KUSET), 12(II): 71-82.

Encyclopedia Britannica (2018a), Feldspar mineral chemical composition available online: https://www.britannica.com/ science/feldspar/ Chemical-composition, accessed on December 10, 2018.

Encyclopedia Britannica (2018b), Quartz mineral. Available online: https://www.britannica.com/ science/quartz, accessed on December 22, 2018.

Foraminifera (2017), Kaolin mining in Nigeria, The pre-feasibility report. Available online: https:// foramfera.com/ marketresearchreports/ miningand-quarrying/kaolin-mining-in-nigeria-the-pre-

feasibility -report/, accessed on December 24, 2017).

Finelib (2017), Feldspar mineral deposits in Nigeria and the enriched states. Available online: https://www.finelib.com/about/nigeria-naturalresources/feldspar-mineral-deposits-in-nigeria-andthe-enriched-states/150, accessed on December 24, 2017.

Hassan S.B. (1993), Refractory properties of some Nigerian clays. Nigerian Society of Engineers Transactions 28(3): 21-25.

Hughes, J.R.T. (2008). Industrialization. International Encyclopedia of the Social Sciences, Thompson Gale, Canada. Available online: http://www. encyclopedia.com/history/United-States-andCanada / us-history/industrialization, accessed on June 12, 2017.

Hobalt M.K. (2018), What is Quartz? Available online: https://geology.com/minerals/quartz.shtml, accessed on May 22, 2018.

Juan A. Medina C. Morán J.M, Guerra M.I. Aguado P.J. Isabel M. Sánchez de Rojas M.I. Frías M. Rodriguez O (2010), Reuse of ceramic wastes in construction. Ceramic Materials, $1^{\text {st }}$ edition, In Technology 197-214. IntechOpen, London, SE19SG, U.K.

Krivandin V and Markov B (1980), Metallurgical furnaces. $1^{\text {st }}$ edition, Moscow: Mir Publishers.

National Research Council of Italy (2017). Ceramic raw materials, Institute of Science and Technology for Ceramics. National Research Council of Italy. Available online: http://www.istec.cnr.it/ index.php/eng/our-research/high-tech-and-nano technology/389-ceramic-row-material, accessed on December 26, 2017.

Projectsxtra (2017), Effect of imported goods on Nigeria Economy (Comparative study). Available online: http://www.projectsxtra.com/resources/ 302.html, Accessed on November 3, 2017.
Ryan W. C. (1978), Properties of ceramic raw materials, U.S.A.: Oxford paragon press, 6.

Safiuddin M. D. Jumaat MZ. Salam M.A. Islam M.S. Hashim R (2010), Utilization of solid wastes in construction materials. International Journal of the Physical Sciences 5(13): 1952-1963.

Shuaib-Babata Y.L. Mudiare E. Egwim C.E. (2016). Suitability of using Ado Ekiti, Akerebiata (Ilorin) and Birni Gwari (Kaduna) clays for production of household ceramic water filter. Journal of Engineering Researc, 21(1): 77-79.

Shuaib-Babata Y.L. Mudiare E (2017), Characterization and evaluation of the refractory properties of local clay deposits in Kwara State, Nigeria. Nigerian Journal of Mechanical Engineering 7(1): 1-21.

Shuaib-Babata Y. L., Abegunde A. J. and Abdul J. M. (2017a), Suitability of Ado-Ekiti (Nigeria) natural moulding sands for use as foundry sands in production of aluminum alloy cast. Journal of Production Engineering, 20(2): 91-100.

Shuaib-Babata Y.L. Yaru S.S. Abdulkareem S. Ajayi S. Busari Y.O. Ajao K.S. Ibrahim H.K. Ambali I.O. Mohammed G.A. (2017b), Suitability of some selected Ado-Ekiti (Nigeria) natural moulding sands' properties for sand casting. Covenant Journal of Engineering Technology (CJET), 1(2): 53-64.

Shuaib-Babata Y. L. Abegunde E. Ambali I.O. (2017c), Evaluation of chemical and physicomechanical properties of Ado-Ekiti (South West, Nigeria) natural moulding sands for foundry applications. Arid Zone Journal of Engineering, Technology and Environment (AZOJETE), 13(5): 718-733.

Torgal F. P. Jalali S (2010), Reusing ceramic wastes in concrete. Construction and Building Materials 24: 832-838.

WIFI Ceramics (2017). The development of ceramic tile industry is inseparable from innovation. Available online: http://www.wificeramics.com /en/ show news.hb?id=17\&dir=1\&nid=4\&pnid=4, accessed on December 24, 2017.

Yoshizawa S. Tanaka M. Shekdar A.V. (2004), Global trends in waste generation. In: recycling, waste treatment and clean technology. TMS mineral, Spain: Metals and Materials Publishers 1541-1552.

Youssef N.F. (2002), Utilization of cement kiln dust in the manufacture of wall tiles. Industrial Ceramics 21(1): 1-8. 